artificial systems of agriculturalists and foresters. Phase 1 (at least three years) is to be devoted to planning to clarify details of the program; basic research at few well equipped stations in the major climatic belts of the world to select, develop and test techniques; exploratory cooperation between scientists of different disciplines; producing a manual on methodology; and training collaborators. Phase 2 (not more than five years) is to see the extension of research to as many stations as possible to ensure world coverage. These stations must meet certain minimum requirements. This program is to be accompanied by establishment of ecological reserves or natural areas in all major vegetation types.

Now where do matters stand? The situation is still rather fuzzy, but a skeleton IBP organization has been set up under the auspices of the International Council of Scientific Unions. A secretary-general (Dr. E. B. Worthington, Nature Conservancy) and coordinating committees for each section have been appointed. The IBP secretariat will request an operating budget of about half a million dollars from participating countries.

The Canadian IBP Committee met at the National Research Council at Ottawa in mid-September and agreed to recommend to NRC that:

1. Canada participate only in projects of a specific, well-defined nature requiring international collaboration.

2. The present ad hoc Committee be replaced by a small national committee of policy-making level in both government and universities to select and coordinate projects in which Canada could participate effectively and to make recommendations on expenditure of public funds for IBP.

3. The coordinating committee set up appropriate panels of experts in the various sections of IBP to direct and co-ordinate research.

Although the proposals are still woolly, I think the general objectives of the project on terrestrial productivity are worthwhile. The idea of the ecosystem as a unit of study and of energy flow as a measure of its 'metabolism' have recently gained acceptance as one of the few unifying concepts in ecology. So far as I know, not a single comprehensive study of a given piece of land and its associated flora, fauna, and air space has ever been made in Canada, and such a study would be valuable for the light it cast on the interactions of elements at work in the ecosystem. We have no notion, for example, what part of the energy flow goes into building a plant crop in comparison with that used in maintaining the ecosystem. The experience of getting foresters, ecologists, soils men, microbiologists, physiologists, biochemists, entomologists, etc., working on the same ecosystem would be invaluable in itself and probably stimulate many unexpected advances in biological research.

Such a program would be expensive even for one well developed station. My back-of-the-envelope calculations suggest a minimum yearly budget of $\$ 500,000$ without considering bricks and mortar.

\title{
Another Professional School of Forestry in Canada
}

At present, the Lakehead College of Arts, Science and Technology at Port Arthur offers a two-year diploma course in forest technology, but for 
several years there has been agitation to establish a degree granting course. I think most of the pressure comes from Prof. John Haggerty, who directs the present technician course-at least this is the impression gained from the brief he circulated last March supporting the proposal.

The kindest thing one can say about this brief is that it is poorly written, rambling and full of non sequiturs. Disregarding this document, however, are there good arguments for this proposal? For example, is there a shortage of foresters in Canada? I don't think so. Our four forestry schools graduated about 110 men in 1964 and will graduate about 200 by 1970 . In addition, there is a continuing trickle of post-graduate students returning from the United States, and of European and American foresters coming to Canada. Moreover, many of the specialists needed by research organizations do not need undergraduate training in forestry.

At the moment, the demand for foresters exceeds the supply in British Columbia because of the enormous expansion of the pulp and paper industry there, but this merely reflects a chronic imbalance that has existed since the War. Numerous openings encourage students to enter forestry; four or five years later when the large classes begin to graduate supply outruns demand, discouraging students from entering forestry, and the cycle starts again.

What Canada is short of is well-trained forestry technicians. In Scandinavia, the ratio of technicians to foresters is about $4: 1$; here it is about 1:1. The present Lakehead course is obviously meeting a real need.

But to continue, has the Lakehead College any unique facilities for a degree-granting course? I don't think so. For many years its supporting faculties will not compare in depth with those at the universities now offering forestry. The proposed minimum faculty for the Lakehead forestry department is woefully inadequate and attracting suitably trained staff would be difficult. Post-graduate training has become essential for most university teachers and good men will not go to a small department that gives undergraduate training only.

The proximity of vast pulpwood forests is helpful, particularly in training technicians who will work mostly in the region, but it is of secondary importance in training professionals whose experience should be broad.

Education is costing vast sums of money and competition for it is stiff. Establishing a good new forestry school would be expensive and Ontario could use the money much more efficiently in expanding the school at the University of Toronto. None of our forestry schools has enough staff, space, or equipment, but if adequately supported they could enlarge their enrolments to meet the foreseeable demand in Canada.

Forestry schools do not get enough first class students now; we need quality more than quantity. The proposal for the Lakehead course is to demand graduation from Grade XII only, in contrast to graduation from Grade XIII required for entrance into other degree courses at the Lakehead College itself. Regardless of one's opinion of the necessity for Grade XIII, as long as passing it at certain standards and in certain subjects is the admission requirement for all Honour and professional courses in Ontario, accepting anything less is an invitation to marginal students to become foresters and will lead to public confusion on the differences between technical and professional education in forestry. 
If the Lakehead College thinks it must establish a degree course in forestry, it should separate the two levels of forestry education now and establish the first year of a degree course based on Grade XIII admission. Additional years could be added as the situation warrants them and meanwhile the students could complete their courses at Toronto or elsewhere. The Lakehead College has ignored this suggestion and should therefore expect no support from the forestry profession.

\section{F. C. Ford Robertson To Edit Multilingual Terminology ${ }^{1}$}

Through an agreement by which the Society of American Foresters will act as agent for the International Union of Forest Research Organizations, the Society has been given the financial support necessary to undertake the preparation of a Multilingual Forestry Terminology.

F. C. Ford Robertson of Oxford, England, has been employed by the Society, effective December 1, 1964, as editor-compiler for the English language portion of the terminology. It is expected that the project will require five years for completion.

Funds in support of the project have been earmarked by the Governments of the United States and Canada, each through its Forest Service. The total amount needed is estimated to be $\$ 100,000$.

Mr. Ford Robertson is a graduate of Edinburgh University who entered the Indian Forest Service in 1924. In 1947 he was appointed director of the Commonwealth Forestry Bureau at Oxford, and editor of Forestry Abstracts.

$\mathrm{He}$ is author of Our Forests and of sundry scientific and bibliographical articles on world forestry subjects. In 1959 there was conferred on him the Order of the British Empire.

Among forestry scientists, forest engineers, wood technologists, and similar workers throughout the world, there has long been need for a Multilingual Forestry Terminology that could be used by international meetings and publications, by conferences of scientists and technicians, by field officers working under international technical assistance programs, and by foresters travelling or studying in foreign countries. Progress in major phases of forestry science is being retarded by lack of precise equivalents of forestry and related terms in the principal languages.

At the Third World Forestry Congress, held in Helsinki in 1949, the delegates charged the Food and Agriculture Organization of the United Nations (FAO) with the preparation of such a terminology.

Because of the financial and technical problems inherent in compiling the terminology, the task of organizing and coordinating the project was undertaken by a Joint Committee on Bibliography, set up by FAO and the International Union of Forest Research Organizations (IUFRO).

In 1955 arrangements were made between the chairman of the Joint Committee and the director of the FAO Forestry Division to start the work in English. A body of English terms and definitions was begun as a result of meetings between representatives of the Society of American Foresters and the Commonwealth Forestry Bureau at Oxford, England. The Bureau is the organizing center for the project. However, the status of the work was not satisfactory because of slow progress.

${ }^{1}$ Reprinted from November 1964, Journal of Forestry. 